\title{
The influence of barley straw extract addition on the growth of duckweed (Lemna valdiviana Phil.) under laboratory conditions
}

\author{
W. Pęczuła ${ }^{(1)}$, M. Suchora(1),^
}

Received May 21, 2014

Revised July 25, 2014

Accepted July 26, 2014

\section{ABSTRACT}

Key-words: duckweed, aquatic weed management, invasive species, barley straw extract, growth inhibition

\begin{abstract}
Due to its ability to forming dense mats in small waterbodies, duckweeds are often considered as nuisance plants in some freshwaters. Up to now, few techniques had been tested aiming towards managing duckweeds, but all of them had appeared to have some disadvantages. As an attempt to find a new effective management tool, a laboratory experiment assessing the influence of barley straw (BS) extract addition - a substance used in algal bloom control, upon the growth of the duckweed Lemna valdiviana, was performed. Reaction on two various concentrations of BS extract were quantified by measurements of changes in duckweed biomass and root length. The results showed that plants which have received the extract increased their biomass slower than that of the control, however only those with the addition of smaller amounts of BS differed significantly from the controls. Furthermore, BS addition stimulated the root growth in both experimental tanks. This implies that the mean roots length was higher, although the statistical differences were insignificant. As possible explanation for the observed changes we suggest that: (1) the growth inhibition of Lemna valvidiana under exposition to BS extract might be induced by an uptake of organic compounds from which some (phenolic substances) are (probably) toxic; (2) competitive interactions with the microbial communities developed upon the duckweed roots might play a role as well.
\end{abstract}

RÉSUMÉ

L'influence d'addition d'extrait de paille d'orge sur la croissance des lentilles d'eau (Lemna valdiviana Phil.) dans des conditions de laboratoire

\author{
Mots-clés : \\ lentilles d'eau, \\ gestion \\ des mauvaises \\ herbes \\ aquatiques, \\ espèces \\ envahissantes, \\ extrait de paille \\ d'orge,
}

Grâce à leur capacité à former des tapis denses dans les petits plans d'eau, les lentilles d'eau sont souvent considérées comme des plantes nuisibles dans certaines eaux douces. Jusqu'à maintenant, quelques techniques ont été testées visant à gérer les lentilles d'eau, mais toutes ont semblé avoir quelques inconvénients. Comme tentative à trouver un nouvel outil de gestion efficace, une expérience de laboratoire évaluant l'influence d'addition d'extrait de paille d'orge (BS), une substance utilisée dans le contrôle de la prolifération des algues, sur la croissance de la lentille d'eau Lemna valdiviana, a été réalisée. La réaction à deux différentes concentrations d'extrait de BS a été quantifiée par des mesures de l'évolution de la biomasse et la longueur des racines de la lentille d'eau. Les résultats ont montré que les plantes qui ont reçu l'extrait ont augmenté leur biomasse

(1) Department of Hydrobiology, University of Life Sciences in Lublin, Dobrzańskiego 37, 20-062 Lublin, Poland

*Corresponding author: magda.suchora@up.lublin.pl 
inhibition plus lentement que celle du témoin, mais seules celles avec l'addition de petites de la croissance quantités de BS différaient significativement des témoins. Par ailleurs, l'addition de BS a stimulé la croissance des racines : dans les deux bassins expérimentaux. Ceci implique que la longueur moyenne des racines était plus élevée, bien que les différences statistiques aient été insignifiantes. Comme explication possible pour les changements observés, nous suggérons que : (1) l'inhibition de la croissance de Lemna valvidiana sous exposition à l'extrait de BS peut être induite par une absorption de composés organiques dont certains (substances phénoliques) sont (probablement) toxiques; (2) des interactions concurrentielles avec les communautés microbiennes développées sur les racines des lentilles d'eau peuvent jouer un rôle.

\section{INTRODUCTION}

Duckweeds (Lemna ssp.), together with other small floating leaves species often form dense mats in ditches, ponds, small lakes and wetlands thus, worsening the underwater light climate and decreasing oxygen content. This strongly influences the conditions for the growth of plankton, submersed macrophytes and macroalgae, fish and macroinvertebrates (Landolt, 1986; Janes et al., 1996; Janse and Van Puijenbroek, 1998; Killgore and Hoover, 2001; Parr et al., 2002; de Tezanos et al., 2007; Pasztaleniec and Poniewozik, 2013). The competition for light and nutrients between floating and submerged plants, as well as the results of this interaction (floating plant domination vs. submerged plant domination) are now regarded as an example of alternative stable states in shallow lakes (Scheffer and Van Nes, 2007). Negative changes induced by duckweeds may also have a profound effect on the conservation status of valuable habitats (e.g. oxbow lakes, which are protected under European law) on conditions in fishponds or may simply reduce the aesthetics of garden ponds (Lewis and Bender, 1961; Pokorný and Rejmánková, 1983; Pęczuła and Banach, 2013). There is also an increasing concern that some duckweeds, being native of the Americas (Lemna valdiviana Phil, Lemna minuta Kunth), have become an invasive alien species in European freshwaters (lberite et al., 2011; Hussner, 2012). Due to their ability for rapid colonization of the aquatic environments by means of vegetative reproduction, they were shown to outcompete native species in nutrientrich conditions (Njambuya et al., 2011).

Duckweeds, when these become a nuisance weed or an undesirable invader, can be controlled by way of mechanical removal, herbicides or fish stocking. Mechanical removal of free floating plants is expensive and often ineffective (Cooke et al., 2005). Previous studies have shown the effectiveness of selected chemicals for the control of the plants; however, results were dependent on application manner and timing (Langeland et al., 2002; Wersal and Madsen, 2009; Cheshier et al., 2011). Furthermore, questions about the safety of this method for fish and other aquatic biota might be raised. Grass carp stocking was proposed as a method of plants removal, as duckweeds are preferred as a food source by this species (Catarino et al., 1997). Nevertheless, the effects of carp stocking seem to have negative environmental consequences, such as eutrophication and increase of phytoplankton biomass (Chilton and Muoneke, 1992; Pípalová, 2006).

In recent years, there has been an increasing interest in the use of barley (Hordeum vulgare L.) straw (BS) as a water quality management tool that appears to be a promising, cheap and environmental-friendly technique in pond and lake restoration (Ó hUallacháin and Fenton, 2010). In terrestrial ecosystems barley is known to have negative effect on growth of other crops and weeds, which results from allelopathy mediated by allelochemicals released from plant components or exuded from living roots. Till now 44 chemicals have been identified as potential allelochemicals that contribute to its allelopathic activity, from which almost a half belongs to phenolic acids (Kremer and Ben-Hammouda, 2009). In aquatic ecosystems the use of barley straw has only been applied to the control of algal blooms. However, some studies reported the influence of BS application on other freshwater biota, including enhanced 
growth of submersed macrophytes, which have come about as an effect of light climate improvement (Caffrey and Monahan, 1999; Ó hUallacháin and Fenton, 2008). Nevertheless, up to now, no research has been found that has directly studied the impact of BS on free floating plants. It has been revealed that adding BS extract to the water results in an increase of dissolved organic carbon concentrations (Pęczuła, 2013). Consequently, this may lead to favouring the habitat conditions for duckweed growth, as some Lemna species do uptake organic compounds (Gorham, 1950; Frick, 1994). On the other hand, phenolic substances are regarded as the main algistatic chemicals leached from rotting BS (Everall and Lees, 1997; Murray et al., 2010), and some of these are also identified as inhibitors of Lemna growth (Toro et al., 1988).

Both positive and negative reaction of duckweeds on BS addition might have practical consequences. With regard to the stimulating action of BS, this will have a great importance in the planning of algal control measures in lake and pond management. If the factor of interest in this paper would inhibit the growth of duckweed it might serve as a potential tool in nuisance weed management. To study the hypothetic effects, we undertook experimental research aimed at determining whether the addition of barley straw $(H$. vulgare) extract has influence upon the growth of small duckweed $L$. valdiviana under laboratory conditions.

\section{MATERIAL AND METHODS}

For the extraction of BS, we prepared an aquarium with a capacity of $16 \mathrm{~L}$, to which $96 \mathrm{~g}$ of dried barley straw (BS) was added, so the resulting dose of straw amounted to $6 \mathrm{~g} \mathrm{BS}$. L ${ }^{-1}$. The tank was filled with dechlorinated tap water and then continuously aerated using a standard aquarium aerator. What is more, it was illuminated with a fluorescent lighting with an irradiance of $25 \mu \mathrm{mol}$ photons $\cdot \mathrm{m}^{-2} \cdot \mathrm{s}^{-1} \cdot 12 \mathrm{~h} \cdot$ day $^{-1}$ and kept at room temperature $\left(21-23^{\circ} \mathrm{C}\right)$ for three months. After the extraction ended, the solution (electrolytic conductivity: $383 \mu \mathrm{S} \cdot \mathrm{cm}^{-1}$, $\mathrm{pH}:$ 7.9, phosphates: $\left.0.093 \mathrm{mg} \cdot \mathrm{L}^{1}\right)$ was filtered through a GF/C fiber glass filter $(1.2 \mu \mathrm{m})$ followed by a single boiling and stored at $4{ }^{\circ} \mathrm{C}$ for one day subsequent to the addition to the experimental tanks.

Lemna valdiviana plants were sampled from the ornamental aquarium located in the Department of Hydrobiology growing room, flushed and then stored for acclimatization for five days in the water sampled from an eutrophic lake, and then filtered through a GF/C fiber glass filter (electrolytic conductivity: $187 \mu \mathrm{S} \cdot \mathrm{cm}^{-1} ; \mathrm{pH}: 7.9$, phosphates: $0.049 \mathrm{mg} \cdot \mathrm{L}^{-1}$ ) During the storage the plants were illuminated with a fluorescent lighting with a colour temperature of $6500 \mathrm{~K}$ (daylight), which gave an irradiance of $45 \mu \mathrm{mol}$ photons $\cdot \mathrm{m}^{-2} \cdot \mathrm{s}^{-1} 12 \mathrm{~h} \cdot$ day $^{-1}$. The samples were kept at $22{ }^{\circ} \mathrm{C}$.

The influence of the extract on duckweed growth was tested in 15 rectangular glass tanks with a capacity of ca. $0.8 \mathrm{~L}$ and the mean water surface area of $0.0045 \pm 0.008 \mathrm{~m}^{2}$. The same amount of water $(0.4 \mathrm{~L})$ sampled from an eutrophic pond and processed as during plant storage was poured into the tanks. Five of them (marked as b2) then received $0.4 \mathrm{~L}$ of the extract, and the other five (marked as b1) $0.2 \mathrm{~L}$ of the extract (these were then topped up with dechlorinated tap water to $0.8 \mathrm{~L}$ ). The doses of the extract were calculated to correspond to $3000 \mathrm{~g}$ of BS and $1500 \mathrm{~g} \mathrm{BS}$ added to $1 \mathrm{~m}^{3}$ of water $\left(3 \mathrm{~g} \cdot \mathrm{L}^{-1}\right.$ and $1.5 \mathrm{~g} \cdot \mathrm{L}^{-1}$, respectively). Five tanks served as controls (marked as c) and were filled with $0.4 \mathrm{~L}$ of pond water and $0.4 \mathrm{~L}$ of dechlorinated tap water. The similar amount $(0.21 \pm 0.02 \mathrm{~g} \mathrm{FW})$ of healthy looking duckweed plants were placed within all the tanks, which were then kept in the same conditions as during plant acclimatization. Before putting the plants into the tanks, 50 specimens were randomly chosen to measure the length of their roots.

The experiment was carried out in July 2013 and lasted 10 days. Evaporation losses were replaced in all tanks twice (ca. $50 \mathrm{~mL}$ ) by dechlorinated tap water. At the first (before duckweed addition) and at the last day (after plants removal) of the research temperature, oxygen concentration, electrolytic conductivity and pH (using the YSI 556 Multi Probe) were measured. Water for laboratory analysis was filtered through a GF/F filter for the determination of: dissolved organic carbon (Pastel Secomam UV analyzer) and phosphates (molybdate method, 


\section{Table I}

Mean ( \pm standard deviation) values of oxygen concentration $\left(\mathrm{O}_{2}\right), \mathrm{pH}$, electrolytic conductivity (EC) concentration of dissolved organic carbon (DOC), phosphates $\left(P_{4}\right)$, duckweed density $(D D)$ and roots length $(R L)$ - at the first $(D+00)$ and last $(D+10)$ day of the experiment $(c-$ controls, b1 - tanks with $1.5 \mathrm{~g} \mathrm{BS} \cdot \mathrm{L}^{-1}$, b2 - tanks with $\left.3 \mathrm{~g} B S \cdot \mathrm{L}^{-1}\right)$.

\begin{tabular}{|l|c|c|c|c|c|c|c|}
\cline { 2 - 7 } \multicolumn{1}{c|}{} & $\begin{array}{c}\mathrm{O}_{2} \\
{\left[\mathrm{mg} \cdot \mathrm{L}^{-1}\right]}\end{array}$ & $\mathrm{pH}$ & $\begin{array}{c}E C \\
{\left[\mu \mathrm{S} \cdot \mathrm{cm}^{-1}\right]}\end{array}$ & $\begin{array}{c}\mathrm{DOC} \\
{\left[\mathrm{mg} \cdot \mathrm{L}^{-1}\right]}\end{array}$ & $\begin{array}{c}\mathrm{PO}_{4} \\
{\left[\mathrm{mg}^{-1} \mathrm{~L}^{-1}\right]}\end{array}$ & $\begin{array}{c}\mathrm{DD} \\
{\left[\mathrm{g} \mathrm{DW} \cdot \mathrm{m}^{-2}\right]}\end{array}$ & $\begin{array}{c}\mathrm{R} L \\
{[\mathrm{~mm}]}\end{array}$ \\
\cline { 2 - 9 } \multicolumn{10}{c|}{$\mathrm{D}+00$} \\
\hline c & $5.1 \pm 0.1$ & $7.6 \pm 0.0$ & $293 \pm 2.8$ & $5.7 \pm 0.5$ & $0.043 \pm 0.007$ & $2.64 \pm 0.4$ & \\
b1 & $5.3 \pm 0.1$ & $8.1 \pm 0.1$ & $289 \pm 1.7$ & $36.5 \pm 1.6$ & $0.034 \pm 0.004$ & $2.87 \pm 0.9$ & $6.1 \pm 2.0$ \\
\hline b2 & $5.6 \pm 0.1$ & $8.4 \pm 0.2$ & $286 \pm 1.6$ & $63.1 \pm 2.1$ & $0.047 \pm 0.012$ & $2.67 \pm 0.5$ & \\
\hline c & $6.6 \pm 0.7$ & $8.5 \pm 0.1$ & $250 \pm 10.9$ & $5.9 \pm 0.8$ & $0.037 \pm 0.018$ & $14.42 \pm 3.9$ & $14.0 \pm 4.8$ \\
b1 & $6.5 \pm 0.2$ & $8.6 \pm 0.1$ & $306 \pm 3.5$ & $32.1 \pm 0.9$ & $0.029 \pm 0.003$ & $9.53 \pm 2.5$ & $18.4 \pm 4.9$ \\
b2 & $5.8 \pm 0.2$ & $8.5 \pm 0.1$ & $324 \pm 1.9$ & $48.0 \pm 3.5$ & $0.039 \pm 0.005$ & $12.14 \pm 3.5$ & $22.2 \pm 5.1$ \\
\hline
\end{tabular}

Dojlido et al., 1999). At the end of the experiment all plants were weighed, their roots were measured and subsequently, they were dried at $80^{\circ} \mathrm{C}$ for $12 \mathrm{~h}$ to determine dry weight (DW). Using the wet to dry weight ratio we then recalculated initial measurements to DW, and taking into account the water surface area of each tank, we presented the results of the duckweed response to the BS addition as changes in their dry weight density $\left(\mathrm{g} \mathrm{DW} \cdot \mathrm{m}^{-2}\right)$. To determine the significance of differences between the control and experimental tanks we carried out ANOVA analysis with Tukey's test using Statistica 6.0 software.

\section{RESULTS}

The initial Lemna valvidiana density in tanks was between $2.64 \pm 0.4 \mathrm{~g} \mathrm{DW} \cdot \mathrm{m}^{-2}$ and $2.87 \pm$ $0.9 \mathrm{~g} \mathrm{DW} \cdot \mathrm{m}^{-2}$. After 10 days, the density increased in all tanks by three to five fold. The higher increase was observed in controls (to $14.42 \pm 3.9 \mathrm{~g} \mathrm{DW} \cdot \mathrm{m}^{-2}$ ), the lowest in b1 tanks (to $9.53 \pm 2.5 \mathrm{~g} \mathrm{DW} \cdot \mathrm{m}^{-2}$ ), while in $\mathrm{b} 2$, the density heightened to $12.14 \pm 3.5 \mathrm{~g} \mathrm{DW} \cdot \mathrm{m}^{-2}$ (Table I, Figure 1). Analysis of variance showed that only the b1 tanks differed significantly from controls (ANOVA, c-b1: $F=5.40, p<0.005$; c-b2: $F=0.94, p=0.360$ ). The initial root length in Lemna plants was $6.08 \pm 2.02 \mathrm{~mm}$. During the experiment we have observed an increase of this value in all tank types (to $13.98 \pm 4.84 \mathrm{~mm}$ in controls), however, contradictory to the plant density, the BS addition seemed to stimulate the root growth. In tanks with 0.2 L of BS (b1) mean root lengths after ten days amounted to $18.38 \pm 4.95 \mathrm{~mm}$ while in tanks with $0.4 \mathrm{~L}$ of BS (b2) it was $22.15 \pm 5.11 \mathrm{~mm}$ (Table l), although the statistical differences between controls and experimental tanks were insignificant (ANOVA, c-b1: $F=33.01, p=4.40$; c-b2: $F=114.33$, $p=1.10)$.

Straw extract added to the tanks induced changes in basic chemical parameters of the water (Table I). We have observed a distinct increase in dissolved organic carbon concentration from $5.7 \pm 0.5 \mathrm{mg} \cdot \mathrm{L}^{-1}$ in controls, to $36.5 \pm 1.6 \mathrm{mg} \cdot \mathrm{L}^{-1}$ in b1 and $63.1 \pm 2.1 \mathrm{mg} \cdot \mathrm{L}^{-1}$ in b2, which was accompanied with a pH increase from $7.6 \pm 0.0$ to $8.1 \pm 0.1$ and $8.4 \pm 0.2$, respectively. $\mathrm{BS}$ addition also resulted in very slight changes of electrolytic conductivity, oxygen and phosphates content. After ten days DOC content decreased in both experimental tanks, while pH, electrolytic conductivity and oxygen concentration increased their values.

\section{DISCUSSION}

This study set out with the aim of assessing the influence of BS extract addition upon the growth of one of the duckweeds - Lemna valdiviana. The results of this study show that plants which have received the extract increased their biomass slower than control ones, however 


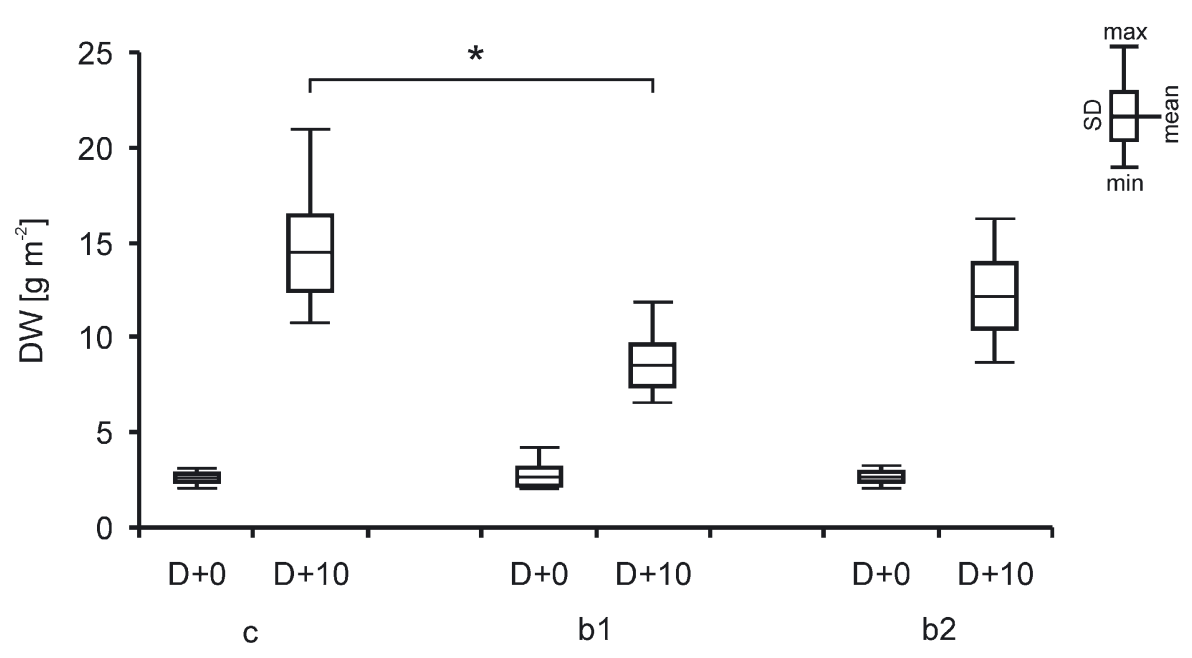

\section{Figure 1}

Duckweed density $\left[\mathrm{g} \cdot \mathrm{m}^{-2}\right]$ in experimental and control tanks at the first $(D+00)$ and last $(D+10)$ day of the experiment (c - controls, b1 - tanks with $1.5 \mathrm{~g} \mathrm{BS} \cdot \mathrm{L}^{-1}$, b2 - tanks with $3 \mathrm{~g} B S \cdot \mathrm{L}^{-1},{ }^{*} \mathrm{p}<0.005$, one-way ANOVA, $N=5)$.

only those with the addition of smaller amount of BS differed significantly from the controls. Another important finding was that the BS addition seemed to stimulate the roots growth in both experimental tanks mean roots length was higher although the statistical differences were insignificant.

Although extensive research has been carried out on the impact of BS addition on algae (Ó hUallacháin and Fenton, 2010), no single study exists which adequately covers other nuisance freshwater biota - including higher plants. Thus, in looking for a possible explanations of our results, we may try to look at the mechanisms of algal inhibition by BS. It is generally accepted that this process is associated with the secretion of various organic compounds, among them phenolic substances that play a key role (Pillinger et al., 1994; Waybright et al., 2009). These compounds are derived from the biodegradation of the lignin in the straw tissues, performed mainly by fungi (Pillinger et al., 1992). Additionally, some researchers pointed at the role of light in the process, and hypothesized, that rotting straw can release precursive compounds which can undergo phototransformation, which can result in production of hydrogen peroxide and other phytotoxic substances (Everall and Lees, 1997). Some phenolic compounds were previously tested for their effect upon various Lemna species. Toro et al. (1988) showed that salicylic acid, ferulic acid and umbelliferone inhibited the growth rate, dry weight and chlorophyll-a production in Lemna gibba. Phenol inhibits stem reproduction of the same duckweed species at $\mathrm{EC}_{50}$ of $0.54 \mathrm{mM}$, it being metabolized by the plant to less toxic phenyl- $\beta$-D-glucoside (Barber et al., 1995). The ability of duckweed for uptaking organic compounds (including phenolic substances) is a well-known phenomenon, which determines the use of these plants as effective phytoremediation agents (Mkandawire and Dudel, 2007). Studies on chlorophenols showed that these compounds are effectively incorporated into the vacuoles and cell walls of Lemna minor (Day and Saunders, 2004). However, an experimental test performed by Yamaga et al. (2010) showed that continuous removal of phenol from the water is not only related to plant uptake, but can be attributed to the beneficial symbiotic interaction between duckweed rhisosphere and bacteria. During the experiment we have observed the development of microbial communities (bacteria, ciliates and diatoms) on the roots of duckweed, which was more intense in the experimental tanks (microscopic observations, data not included in the Results) rather than in the control. These may explain the root elongation in the experimental plants. Duckweeds extend their root length in response to phosphate starvation (Reid and Bieleski, 1970). This might occur when rich epiphytic communities develop within the macrophyte rhisosphere (Roijackers et al., 2004). 
In conclusion, we can put forward the hypothesis that the growth inhibition of $L$. valvidiana under exposition to BS extract might be induced by an uptake of organic compounds (decrease in DOC concentrations in experimental tanks) from which some (phenolic substances) occurred to be toxic. Interactions with microbial communities developed on duckweed roots may play a role as well. However, the more inhibiting effect of lower BS dose is still not clear. The present findings of our short preliminary study seem to be consistent with other research. This found the inhibition of duckweed growth by the addition of various plants extracts (Sutton and Portier, 1989). Similarly to this study we have not identified the chemical composition of BS extract, but have only pointed out this as a new potential tool for nuisance duckweed management. However, more research (including field studies, other duckweed species and chemical identification of BS extract) needs to be undertaken before the association between barley straw and Lemna growth inhibition is more clearly understood.

\section{REFERENCES}

Barber J.T., Sharma H.A., Ensley H.E., Polito M.A. and Thomas D.A., 1995. Detoxification of phenol by the aquatic angiosperm, Lemna gibba. Chemosphere, 31, 3567-3574.

Caffrey J.M. and Monahan C., 1999. Filamentous algal control using barley straw. Hydrobiologia, 415, 315-318.

Catarino L.F., Ferreira M.T. and Moreira I.S., 1997. Preferences of grass carp for macrophytes in Iberian drainage channels. J. Aquat. Plant Manage., 35, 79-83.

Cheshier J.C., Wersal R.M. and Madsen J.D., 2011. NOTES - The susceptibility of duckweed (Lemna minor L.) to fluridone and penoxsulam. J. Aquat. Plant Manage., 49, 50.

Chilton II E.W. and Muoneke M.I., 1992. Biology and management of grass carp (Ctenopharyngodon idella, Cyprinidae) for vegetation control: a North American perspective. Rev. Fish Biol. Fish., 2, 283-320.

Cooke G.D., Welch E.B., Peterson S. and Nichols S.A., 2005. Restoration and management of lakes and reservoirs. CRC Press, Boca Raton, 575 p.

Day J.A. and Saunders F.M., 2004. Glycosidation of chlorophenols by Lemna minor. Environ. Toxicol. Chem., 23, 613-620.

De Tezanos Pinto P., Allende L. and O'Farrell I., 2007. Influence of free-floating plants on the structure of a natural phytoplankton assemblage: an experimental approach. J. Plankton Res., 29, 47-56.

Dojlido J., Dożańska W., Hermanowicz W., Koziorowski B. and Zerbe J., 1999. Fizyczno-chemiczne badanie wody i ścieków [Physico-chemical examination of water and wastewater], Arkady, Warszawa, 566 p. (in Polish)

Everall N.C. and Lees D.R., 1997. The identification and significance of chemicals released from decomposing barley straw during reservoir algal control. Water Res., 31, 614-620.

Frick H., 1994. Heterotrophy in the Lemnaceae. J. Plant Physiol., 144, 189-193.

Gorham P.R., 1950. Heterotrophic nutrition of seed plants with particular reference to Lemna minor L.. Can. J. Res., 28, 356-381.

Hussner A., 2012. Alien aquatic plant species in European countries. Weed Res., 52, 297-306.

Iberite M., lamonico D., Abati S. and Abbate G., 2011. Lemna valdiviana Phil. (Araceae) as a potential invasive species in Italy and Europe: Taxonomic study and first observations on its ecology and distribution. Plant Biosyst., 145, 751-757.

Janes R., Eaton J. and Hardwick K., 1996. The effects of floating mats of Azolla filiculoides Lam. and Lemna minuta Kunth on the growth of submerged macrophytes. Hydrobiologia, 340, 23-26.

Janse J.H. and Van Puijenbroek P.J.T.M., 1998. Effects of eutrophication in drainage ditches. Environ. Poll., 102, 547-552.

Killgore K.J. and Hoover J.J., 2001. Effects of hypoxia on fish assemblages in a vegetated waterbody. J. Aquat. Plant Manage., 39, 40-44.

Kremer R.J. and Ben-Hammouda M., 2009. Allelopathic Plants. 19. Barley (Hordeum vulgare L). Allelopathy J., 24, 225-242. 
Landolt E., 1986. The family of Lemnaceae - a monographic study, vol. 1. Biosystematic investigations in the family of duckweeds (Lemnaceae). Veröffentlichungen des Geobotanischen Institutes der ETH, Stiftung Rübel, Zürich, 566 p.

Langeland K.A., Hill O.N., Koschnick T.J. and Haller W.T., 2002. Evaluation of a new formulation of Reward landscape and aquatic herbicide for control of duckweed, waterhyacinth, waterlettuce, and hydrilla. J. Aquat. Plant Manage., 40, 51-53.

Lewis W.M. and Bender M., 1961. Effect of a cover of duckweeds and the alga Pithophora upon the dissolved oxygen and free carbon dioxide of small ponds. Ecology, 42, 602-603.

Mkandawire M. and Dudel E.G., 2007. Are Lemna spp. effective phytoremediation agents. Bioremediation, Biodiversity and Bioavailability, 1, 56-71.

Murray D., Jefferson B., Jarvis P. and Parsons S.A., 2010. Inhibition of three algae species using chemicals released from barley straw. Environ. Technol., 31, 455-466.

Njambuya J., Stiers I. and Triest L., 2011. Competition between Lemna minuta and Lemna minor at different nutrient concentrations. Aquat. Bot., 94, 158-164.

Ó hUallacháin D. and Fenton O., 2008. Artificial lake amelioration: implications for submerged aquatic vegetation. In: Proceedings of Environ, Dundalk, Rep. of Ireland, 92.

Ó hUallacháin D. and Fenton O., 2010. Barley (Hordeum vulgare)-induced growth inhibition of algae: a review. J. Appl. Phycol., 22, 651-658.

Parr L., Perkins R. and Mason C., 2002. Reduction in photosynthetic efficiency of Cladophora glomerata, induced by overlying canopies of Lemna spp. Water Res., 36, 1735-1742.

Pasztaleniec A. and Poniewozik M., 2013. The impact of free-floating plant cover on phytoplankton assemblages of oxbow lakes (The Bug River Valley, Poland). Biologia, 68, 18-29.

Pęczuła W., 2013. Influence of barley straw (Hordeum vulgare L.) extract on phytoplankton dominated byScenedesmus species in laboratory conditions: the importance of the extraction duration. J. Appl. Phycol., 25, 661-665.

Pęczuła W. and Banach B., 2013. Small water bodies and lakes protected under EU Habitat Directive results of the pilot wildlife monitoring in the Lublin Region. TEKA Komisji Ochrony i Kształtowania Środowiska Przyrodniczego, 10, 306-317.

Pillinger J.M., Cooper J.A., Ridges I. and Barrett P.R.F., 1992. Barley straw as an inhibitor of algal growth III: the role of fungal decomposition. J. Appl. Phycol., 4, 353-355.

Pillinger J.M., Cooper J.A. and Ridge I., 1994. Role of phenolic compounds in the antialgal activity of barley straw. J. Chem. Ecol., 20, 1557-1569.

Pipalova I., 2006. A review of grass carp use for aquatic weed control and its impact on water bodies. J. Aquat. Plant Manage., 44, 1-12.

Pokorný J. and Rejmánková E., 1983. Oxygen regime in a fishpond with duckweeds (Lemnaceae) and Ceratophyllum. Aquat. Bot., 17, 125-137.

Reid M.S. and Bieleski R.L., 1970. Response of Spirodela oligorrhiza to phosphorus deficiency. Plant Physiol., 46, 609-613.

Roijackers R., Szabo S. and Scheffer M., 2004. Experimental analysis of the competition between algae and duckweed. Arch. Hydrobiol., 160, 401-412.

Scheffer M. and van Nes E., 2007. Shallow lakes theory revisited: various alternative regimes driven by climate, nutrients, depth and lake size. Hydrobiologia, 584, 455-466.

Sutton D.L. and Portier K.M., 1989. Influence of allelochemicals and aqueous plant extracts on growth of duckweed. J. Aquat. Plant Manage., 27, 90-95.

Toro G.R., Leather G.R. and Einhellig F.A., 1988. Effects of three phenolic compounds on Lemna gibba G3. J. Chem. Ecol., 14, 845-853.

Waybright T.J., Terlizzi D.E. and Ferrier M.D., 2009. Chemical characterization of the aqueous algistatic fraction of barley straw (Hordeum vulgare) inhibiting Microcystis aeruginosa. J. Appl. Phycol., 21, 333-340.

Wersal R.M. and Madsen J.D., 2009. Combinations of diquat and a methylated seed oil surfactant for control of common duckweed and watermeal. J. Aquat. Plant Manage., 47, 59-62.

Yamaga F., Washio K. and Morikawa M., 2010. Sustainable biodegradation of phenol by Acinetobacter calcoaceticus P23 isolated from the rhizosphere of duckweed Lemna aoukikusa. Environ. Sci. Technol., 44, 6470-6474. 